\title{
TEMBANG MACAPAT SEBAGAI PENUNJANG PENDIDIKAN KARAKTER
}

\author{
Puji Anto ${ }^{1}$, Tri Anita ${ }^{2}$ \\ ${ }^{1}$ Program Studi Desain Komunikasi Visual, Fakultas Bahasa dan Seni \\ ${ }^{2}$ Program Studi Pendidikan Ekonomi, Fakultas Ilmu Pendidikan dan Pengetahuan Sosial \\ Universitas Indraprasta PGRI \\ Ipujianto@unindra.ac.id, ${ }^{2}$ tri.anita@unindra.ac.id
}

\begin{abstract}
Abstrak
Tujuan penelitian ini adalah mengintepretasikan larik tembang macapat, khususnya tembang mijil sebagai penunjang pendidikan karakter. Jenis penelitian yang digunakan adalah penelitian pustaka. Untuk mempertajam analisis metode deskriptif kualitatif, maka digunakanlah teknik analisis isi, yaitu analisis ilmiah berdasarkan isi pesan dalam komunikasi. Proses analisis isi dimulai dengan pemaknaan bahasa Jawa ke bahasa Indonesia, bentuk bahasa Indonesia tersebut dimaknai secara harfiah, dan dilanjutkan dengan analisis kritis dan objektif yang dikaitkan pendidikan karakter. Hasil dari penelitian ini berupa nilai-nilai pendidikan karakter yang ada dalam tembang mijil, nilai-nilai itu di antaranya pintar, merendah, mengalah, jangan membantah, kesederhanaan, dan jangan menggunjing. Suatu keniscayaan bahwa masyarakat dan para pelaku pendidikan mampu menggali nilai-nilai budaya atau kearifan lokal untuk memberikan stimulus dalam pembelajaran dengan nuansa yang berbeda, tentunya menggunakan media yang menarik dan menyenangkan.
\end{abstract}

Kata Kunci: tembang, macapat, mijil, pendidikan, karakter.

\begin{abstract}
The purpose of this research is to interpret the lyrics of the song gained particular song mijil as supporting character education. This type of research is the study of the literature. To sharpen the analysis of qualitative descriptive method, then the unambiguous content analysis techniques, namely scientific analysis based on the content of the messages in the communication. Contents of the analysis process begin with a definition of the Java language to the language of Indonesia, the Indonesia language form is meant literally, and continued with a critical and objective analysis that linked character education. The results of this research in the form of values character education that exists in the mijil song, those values that reflected in the mijil song are smart, modest, compliant, do not argue, simplicity, and do not gossip. An inevitability that the community and the principals of education were able to unearth the cultural values or local wisdom to provide stimulus in learning with different shades, of course using media that is interesting and fun.
\end{abstract}

Keywords: song, macapat, mijil, education, character

\section{PENDAHULUAN}

Karya sastra merupakan representasi ide dan gagasan dari pengarang yang syarat akan nilai-nilai atau pesan tentang kehidupan. Karya sastra tidak hanya merujuk pada satu bidang kehidupan saja, tetapi juga mampu masuk ke berbagai bidang dalam kehidupan manusia, seperti psikologi, kebudayaan, ekonomi, sosial, politik, dan pendidikan. Karya sastra mampu menginspirasi pembacanya 
untuk memahami tentang pesan-pesan kehidupan yang ada pada teks/ naskahnya. Dengan membaca karya sastra, pembaca seakan-akan mendapatkan petuah-petuah dan bahkan dapat memotret kisah kehidupan yang tergambar dalam ceritanya.

Larik yang ada pada lagu atau tembang dianggap sebagai karya sastra, yaitu puisi. Tembang dalam KBBI pada pengertian poin dua berarti 'puisi'(Badan Pengembangan dan Pembinaan Bahasa, 2016). Lagu atau tembang merupakan rangkaian katakata yang diiramakan dengan bunyi dan mengedepankan harmonisasi. Setiap kata yang muncul dalam lagu/tembang tersebut tentunya tidak hanya bunyibunyian saja. Pengarang pasti punya maksud-maksud tertentu atau pesanpesan yang ingin disampaiakan melalui liriknya, tetapi dengan sederhana dan menyenangkan (Rahman \& Anto, 2015).

Musik atau lagu mampu menjadi jembatan dalam menyampaikan pesanpesan moral. Lagu atau musik dapat menjadi sumber edukatif dalam membangun karakter manusia. Musik atau lagu juga terbukti mampu memengaruhi hidup seseorang. Dengan mendengarkan musik, suasana batin seseorang dapat terpengaruhi. Akhirnya, karena mampu mempengaruhi batin seseorang, secara tidak langsung musik mampu menamkan nilai-nilai luhur yang tertuang dalam lagunya untuk menjadi karakter bagi pendengarnya.

Musik, lagu, atau tembang sudah dikenal masyarakat Indonesia sejak zaman dulu. Bahkan menurut sejarahnya, khususnya sejarah Islam, tembang digunakan sebagai media untuk menyebarkan nilai-nilai Islam, contohnya adalah Wali Songo. Berdasarkan sejarahnya, bahwa dalam menyebarkan Islam, Wali Songo selalu menggunakan syair atau tembang- tembang yang disesuaikan dengan bahasa keseharian masyarakat pada waktu itu. Wali Songo identik dengan daerah atau wilayah dengan suku Jawa. Oleh sebab itu, penyebaran ajaran Islam di Pulau Jawa yang dilakukan oleh Wali Songo boleh dibilang berhasil, hal itu dibuktikan dengan banyaknya pemeluk agama Islam. Banyak petuah-petuah atau ungkapan dalam bahasa Jawa yang tertuang dalam lagu atau tembang tersebut. Saat ini, tembang-tembang tersebut sebenarnya masih dipelajari di sekolah-sekolah, khususnya daerah Jawa Tengah sebagai mata pelajaran muatan lokal (Mulok) dan sering dilantunkan dalam acara-acara pentas kesenian, seperti wayang dan ketoprak. Namun, yang menjadi permasalahan adalah kurangnya pemahaman akan makna yang terkandung.

Banyak sekali tembang-tembang atau lagu berbahasa Jawa, contohnya adalah tembang Macapat. Tembang macapat merupakan gambaran perjalanan manusia dimulai dari dalam kandungan sampai dengan meninggal, yaitu dari Maskumambang (janin dalam Rahim ibu), mijil (lahir), sinom (muda), asmarandana (memadu asmara), gambuh (kecocokan antara laki-laki dan perempuan), dhandhanggula (menjadi manusia dewasa), kinanthi (mendidik anak), pangkur (prinsip dalam hidup), durma (berderma), megatruh (berpisahnya ruh dan raga), dan pucung (dipocong atau meninggal). Setiap tembang dalam macapat terkandung nilai-nilai moral, budi pekerti, dan petunjuk tentang perilaku yang harus dilakukan oleh manusia dari lahir sampai dengan meninggal dunia agar mendapat kemuliaan hidup dunia dan akhirat.

Faktanya juga, nilai-nilai yang terkandung dalam tembang macapat sudah ditinggalkan oleh generasi muda karena globalisasi dan perubahan 
kurikulum pendidikan yang berorientasi pada ilmu pengetahuan dan teknologi modern (Efendi, 2009).

Oleh sebab itu, sangat diperlukan sebuah kajian tentang budaya-budaya maupun kearifan lokal untuk memberikan edukasi kepada halayak, khususnya generasi muda atau bahkan kepada anak yang baru lahir atau peserta didik baru dalam sebuah lembaga pendidikan. Pendidikan harus diberikan sedini mungkin sebagai bentuk pembiasaan dan dari kebiasaan tersebut terbentuklah karakter. Untuk itu, pada penelitian ini akan dibahas tentang makna yang terkandung dalam tembang macapat agar dapat diteladani dan mampu membentuk karakter manusia. Untuk membatasi objek kajian, maka pada penelitian ini terfokus pada tembang macapat mijil. Pemilihan tembang mijil berdasarkan pada pendapat bahwa pendidikan manusia dapat dimulai sejak lahir. Hal itu sesuai dengan pendapat kaum empiris yang sangat memegang pendirian bahwa pengetahuan manusia dapat diperoleh melalui pengalaman (Munir, 2004). Pengalaman yang dimaksud adalah segala proses perilaku yang didapat dari lahir sampai meninggal. Jadi, pengalamanlah yang menentukan seseorang untuk mempunyai kecerdasan, baik secara emosional maupun intelektul.

Diharapkan, dengan adanya kajian-kajian budaya dan kearifan lokal dapat menjadi jawaban degradasi moral anak zaman sekarang. Anak zaman sekarang lebih kepada menyerap atau meniru budaya-budaya global daripada memahami kebudayaan yang ada di sekitarnya. Hal itu juga termasuk kebiasaan anak-anak dalam bermusik. Seribu satu jika ada seorang anak mau menyanyikan atau melestarikan tembang-tembang daerah, khususnya tembang Jawa. Mereka lebih bangga jika bermusik mengacu pada keinternasion, padahal budaya global tersebut belum tentu bermakna atau sesuai dengan tata aturan dan adatistiadat yang ada di negara maupun lingkungannya, contohnya tentang kesopanan, kesabaran, dan kemanfaatan. Kesopanan di era sekarang dapat dipahami terkait cara berpakaian, kesabaran dapat dipahami terkait pengendalian emosi yang mengakibatkan kekerasan, kemanfaatan dapat dipahami sebagai semangat untuk menjadi pintar agar dapat berguna untuk sesamanya.

Berdasarkan beberapa contoh di atas, maka sangat diperlukan sebuah cara untuk memberikan edukasi terkait pesan-pesan moral, salah satunya melalui karya sastra. Karya sastra yang dimaksud adalah dengan menggunakan tembang-tembang yang berasal atau berbahasa Jawa. Tentunya, kemanfaatan tembang ini tidak hanya tertuju pada suku Jawa saja, tetapi dapat juga ditularkan pada suku yang lain. Indonesia punya bahasa Indonesia yang mampu memfasilitasi kebudayaan yang ada. Saat ini, sebuah budaya dari suku tertentu tidak hanya dapat dipahami oleh kelompok tersebut saja, tetapi dengan bahasa Indonesia, antarsuku dapat saling mengenal atau memahami budaya yang satu dengan yang lainnya. Ada petuah mengatakan "jangan melihat darimana kebaikan itu berasal, tetapi lihatlah pesan kebaikannya".

Untuk menyamakan persepsi terkait kajian dalam penelitian ini, maka perlu disampaiakan beberapa penegasan terhadap ungkapan-ungkapan yang tertuang dalam judul, yaitu sebagai berikut:

\section{Pendidikan Karakter}

Undang-undang No. 20 tahun 2003 pasal I ayat I tentang sistem pendidikan Nasional, menyebutkan 
bahwa: Pendidikan adalah usaha sadar dan terencana untuk mewujudkan suasana belajar dan proses pembelajaran agar peserta didik secara aktif mengembangkan potensi dirinya untuk memiliki kekuatan spiritual keagamaan, pengendalian diri, kecerdasan, akhlak mulia, serta keterampilan yang diperlukan dirinya, masyarakat, bangsa dan negara. Menurut Kamus Besar Bahasa Indonesia, Pendidikan berarti proses pengubahan sikap dan tata laku seseorang atau kelompok orang dalam usaha mendewasakan manusia melalui upaya pengajaran dan pelatihan (Badan Pengembangan dan Pembinaan Bahasa, 2016). Jadi, dapat disimpulkan bahwa pendidikan adalah sebuah usaha atau cara dalam membentuk perilaku yang baik.

Karakter menurut Kamus Besar Bahasa Indonesia adalah sifat-sifat kejiwaan, akhlak atau budi pekerti yang membedakan sesorang dari yang lain (Badan Pengembangan dan Pembinaan Bahasa, 2016). Karakter menurut Thomas Lickona adalah watak batin yang dapat diandalkan dan digunakan untuk merespon berbagai situasi dengan cara yang bermoral. Selain itu, karakter juga dapat dianggap sebagai nilai-nilai perilaku manusia yang berhubungan dengan Tuhan Yang Maha Esa, diri sendiri, sesama manusia, lingkungan, dan kebangsaan yang terwujud dalam pikiran, sikap, perasaan, perkataan dan perbuatan berdasarkan norma-norma agama, hukum, tata krama, budaya, adat istiadat dan estetika (Lickona, 2013). Berdasarkan pendapat di atas, karakter adalah pembeda antara manusia yang satu dengan manusia yang lain, baik dalam urusan dengan Tuhannya maupun lingkungannya. Jadi, berdasarkan pendapat tentang pendidikan dan karakter, maka pendidikan karakter ialah sebuah upaya untuk membimbing perilaku manusia menuju individu yang berguna, baik secara vertikal maupun horisontal.

Dalam penelitian ini, penulis berusaha mengkaji nilai-nilai pendidikan karakter yang terdapat dalam tembang mijil tanpa membatasi perilaku tertentu.

\section{Seni Musik}

Seni dalam Kamus Besar Bahasa Indonesia (KBBI) mempunyai arti keahlian membuat karya yang bermutu (dilihat dari kehalusannya, keindahannya, dan sebagainya) (Badan Pengembangan dan Pembinaan Bahasa, 2016). Musik dalam Kamus Besar Bahasa Indonesia (KBBI) berarti nada atau suara yang disusun sedemekian rupa sehingga mengandung irama, lagu, dan keharmonisan (terutama yang menggunakan alat-alat yang dapat menhasilkan bunyi) (Badan Pengembangan dan Pembinaan Bahasa, 2016). Dari pengertian di atas, dapat disimpulkan bahwa seni musik adalah karya yang bermutu dalam hal susunan nada atau suara yang harmonis.

Seni musik yang dimaksud dalam penelitian ini adalah seni musik yang dapat menjadi media dalam pendidikan karakter seseorang, dalam hal ini seni musik yang dimaksud adalah tembang tradisional.

\section{Tembang Macapat}

Tembang menurut Kamus Besar Bahasa Indonesia (KBBI) ialah syair yang diberi lagu (untuk dinyanyikan) dan pengertian macapat dalam kultur Jawa merupakan bentuk puisi Jawa Tradisional, setiap baitnya mempunyai baris kalimat (gatra) tertentu, setiap gatra mempunyai jumlah suku kata (guru wilangan) tertentu, dan berakhir pada bunyi sanjak akhir (guru lagu; guru suara tertentu) (Badan Pengembangan dan Pembinaan Bahasa, 2016). 
Dapat disimpulkan bahwa tembang macapat merupakan syair atau puisi Jawa tradisonal dengan berbagai ketentuan dalam melagukan. Tembang macapat yang dimaksud dalam penelitian ini adalah tembang mijil.

\section{METODE PENELITIAN}

Jenis penelitian yang digunakan adalah penelitian pustaka (library research). Penelitian pustaka ialah menjadikan bahan-bahan pustaka berupa buku, artikel ilmiah, skripsi, dan materi lainnya sebagai sumber dalam penelitian.

Untuk mempertajam analisis metode deskriptif kualitatif, maka digunakanlah teknik analisis isi, yaitu analisis ilmiah berdasarkan isi pesan dalam komunikasi (Sahlan \& Mulyana, 2012). Proses analisis isi dalam penelitian ini dimulai dengan pemaknaan bahasa Jawa ke bahasa Indonesia, bentuk bahasa Indonesia tersebut dimaknai secara harfiah, dan dilanjutkan dengan analisis kritis dan objektif yang dikaitkan pendidikan karakter.

Pemaknaan yang dimaksud juga menggunakan metode parafrasa, Aminudin dalam Nuratni dkk. mengatakan bahwa ada bermacam metode yang dapat membantu memaknai sebuah puisi atau tembang (Tembang adalah puisi yang dilagukan dan identik dengan suku Jawa), salah satunya adalah metode parafrasa. Parafrasa berarti menguraikan dengan kata sendiri. Parafrasa merupakan strategi pemahaman kandungan makna dengan mengungkapkan kembali gagasannya dengan ungkapan yang berbeda dari pengarangnya (Nuratni, Artawan, \& Sutresna, 2014).

\section{HASIL DAN PEMBAHASAN}

Tembang Mijil berarti seorang anak yang terlahir. Mijil dalam bahasa
Jawa dapat berarti wijil, wiyos, raras, medal, sulastri yang berarti 'keluar'. Ketika bayi lahir saat itulah pertama kali mengenal dunia dan menjalani kehidupan selanjutnya. yaitu:

Karakteristik tembang mijil

a. Guru Gatra: patokan di setiap barisnya, memiliki 6 baris.

b. Guru Lagu: patokan aksara diakhir kata, i, a/o, e, i, i, a/o

c. Guru Wilangan: patokan jumlah suku kata, 10, 6, 10, 10, 6, 6 (Efendi, 2009).

Tembang Mijil ini memiliki seperangkat tata nilai dan etika yang digunakan dalam konteks masyarakat Jawa. Salah satu tembang mijil yang terkenal adalah sebagai berikut:

Dedalane guno lawan sekti

kudu andhap asor

Wani ngalah dhuwur wekasane

Tumungkula yen dipun dukani

Bapang den simpangi

ono catur mungkur

(Pitaloka, 2017)

Berikut merupakan kajian terkait syair dalam tembang macapat, khusunya tembang mijil yang nantinya dapat dipergunakan sebagai sarana dalam aplikasi pendidikan karakter.

\section{Dedalane guno lawan sekti.}

Jika dimaknai ke dalam bahasa Indonesia, maka dedalane berarti 'jalannya', guno berarti 'untuk', lawan dapat diartikan 'meraih', sekti mengandung arti 'sakti' atau 'pintar'. Dari maknamakna tersebut, jika dikait dengan kata mijil (lahir), maka baris di atas dapat diartikan bahwa lahir merupakan sebuah jalan seseorang untuk bisa menjadi pintar. Dapat juga diartikan sebuah jalan untuk mencapai kemuliaan. Jalan yang dimaksud dapat diartikan sebagai 
awal perjalanan manusia dalam menempuh pendidikan, contohnya adalah menjadi peserta didik baru dalam sebuah lembaga pendidikan.

$$
\text { Nilai karakter yang }
$$

ditanamkan dalam baris tersebut adalah setiap manusia yang lahir ke dunia atau awal menempuh sebuah pendidikan harus berorientasi pada kecerdasan atau kepintaran untuk merespon tuntutan zaman. Kecerdasan atau kepintaran seseorang akan mampu menempatkan dirinya pada tempat yang terbaik/ mulia. Lebih lanjut, berhubungan dengan kepintaran, maka pasti ada kaitannya dengan kebermanfaatan. Nilai karakter yang tergambar pada baris ini mungkin sebagai jawaban atas kondisi saat ini, contohnya terkait dengan kemiskinan dan pengangguran. Kecerdasan berasal dari kata dasar cerdas yang berarti sempurna perkembangan akal budinya untuk berpikir, mengerti, dan sebagainya atau tajam pikiran (Badan Pengembangan dan Pembinaan Bahasa, 2016).

\section{Kudu andhap asor.}

Kudu dalam bahasa Indonesia berarti 'harus', andap asor dapat diartikan sebagai 'merendah'. Secara harfiah baris ini menegaskan akan pentingnya mempunyai perilaku merendah atau dapat dikatakan rendah hati. Nilai karakter ini menekankan pada suatu perilaku yang selalu menghargai orang lain. Hal itu sebagai bentuk menempatkan orang lain selalu lebih tinggi, dihargai, dihormati, tidak peduli apakah dia pejabat atau bukan pejabat, orang pandai atau tidak, tetap harus menghargainya sebagai sesama manusia.
Dalam konteks pendidikan, dengan rendah hati maka pergaulan akan menjadi luas. Hal itu akan berdampak pada banyaknya pengetahuan yang didapat akibat dari beragamnya individu yang notabene mempunyai pengetahuan dan pemikiran.

Rendah hati dalam Kamus Besar Bahasa Indonesia berarti sifat yang tidak sombong atau tidak anggkuh (Badan Pengembangan dan Pembinaan Bahasa, 2016). Sifat ini merupakan nilai yang dapat dijadikan penangkal atas beberapa fenomena di masyarakat, seperti perilaku narsistik atau merasa paling segalanya.

\section{Wani ngalah dhuwur wekasane.}

Baris di atas jika dimaknai satu-persatu ialah wani berarti berani', ngalah yaitu 'mengalah', dhuwur artinya tinggi, dan wekasane adalah 'pesannya'. Secara harfiahnya adalah berani mengalah itu tinggi pesannya atau dapat diartikan mengalah punya nilai yang tinggi/ baik. Mengalah juga dapat diartikan mampu mengendalikan atau memimpin diri sendiri. Nilai karakter mengalah dapat menjadi solusi terjadinya perdebatan. Saat ini di media masa banyak sekali dipertontonkan perilaku-perilaku saling menjatuhkan satu dengan yang lainnya. Begitu juga beberapa kasus yang terjadi dalam dunia pendidikan, banyak sekali perkelahian dan tawuran.

Mengalah juga dapat dikatagorikan menjadi tiga, yaitu mengalah yang berarti menghindari, mengalah yang berarti pura-pura, dan mengalah karena ada yang lebih baik. Hal itu sesuai dengan apa yang tertuang dalam Kamus Besar Bahasa Indonesia, mengalah berarti tidak 
mau mempertahankan haknya, pendiriannya; dengan sengaja kalah; pura-pura (Badan Pengembangan dan Pembinaan Bahasa, 2016).

\section{Tumungkula yen dipun dukani.}

Tumungkula berarti 'diam', yen berarti 'kalau', dipun berarti 'sedang', dan dukani berarti 'dimarahi'. Secara harfiah baris ini berarti jangan membantah bila dimarahi' atau dapat dikatakan 'mau menerima kritik dan saran', lebih sederhananya adalah 'lapang dada'. Hal itu senada dengan pepatah 'diam itu emas', apalagi jika telah melakukan kesalahan. Jangan membantah atau lapang dada berarti merasa lega, senang, dan tidak menjadi gusar (Badan Pengembangan dan Pembinaan Bahasa, 2016). Jadi, dalam konteks pendidikan kaitannya dengan proses belajar-mengajar, jika mendapatkan teguran, sikap yang harus diambil adalah intropeksi diri dan menerimanya dengan lapang dada.

Kata dukani/ dimarahi dapat diperluas maknanya tidak hanya oleh orang lain, tetapi juga bisa oleh 'kehidupan', 'alam', dan 'Sang Pencipta'. Bencana yang bersifat kecil atau besar, menimpa diri pribadi atau umat, dapat juga diartikan sedang 'dimarahi' maka sikap yang dilakukan adalah tidak membantah, merenung, dan lapang dada.

Sebagai contoh, nilai karakter ini dapat diterapkan terkait dengan perilaku-perilaku suporter dalam olahraga apa pun. Banyak kasus/kejadian-kejadian karena yang didukung kalah akhirnya melakukan tindakan anarki. Suporter seharusnya tidak hanya menerima kemenangan, tetapi juga menerima kekalahan.

\section{Bapang den simpangi.}

Bapang ada yang mengartikan sebagai 'jabatan'. Jabatan identik dengan kemewahan. Den berarti 'sebaiknya', dan simpangi berarti 'hindari'. Baris ini dapat diartikan bahwa 'kemewahan sebaiknya dihindari'. Sederhananya, nilai karakter yang ada dalam baris tersebut adalah kesederhanaan. Dalam KBBI kesederhanaan yang diambi dari jata dasar sederhana berarti bersahaja, tidak berlebihlebihan; sedang (dalam arti pertengahan); tidak banyak selukbeluknya (Badan Pengembangan dan Pembinaan Bahasa, 2016). Nilai karakter sederhana saat ini sudah mulai ditinggalkan oleh masyarakat. Masyarakat sekarang cenderung memuaskan dirinya sendiri dengan perilaku berhura-hura. Dalam dunia pendidikan pun demikian, lembaga pendidikan merupakan ajang untuk menunjukkan apa yang dimiliki (terkait harta), bukan lagi menjadi ajang menunjukkan kualitas intelektualnya.

Konotasi 'bapang' yang berarti 'kemewahan' juga dapat diperluas artinya menjadi hal yang kamuflase, mengedapankan eksistensi dan pencitraan, serta suka dipuji.

\section{Ono catur mungkur.}

Ono berarti 'ada', catur berarti 'pembicaraan', mungkur berarti 'menyingkir'. Baris yang terakhir ini makna harfiahnya adalah 'menjauhi keburukan'. Keburukan yang dimaksud sangat luas, misalnya pergunjingan. pergunjingan pasti diawali dengan prasangka buruk. Pergunjingan adalah perilaku tidak baik yang membicarakan kekurangan atau kejelekan orang lain. KBBI 
memberikan arti pada kata menggunjing dengan membicarakan kekurangan orang lain; mengumpat; memfitnah (Badan Pengembangan dan Pembinaan Bahasa, 2016).

Makna dalam bait ini sangat menginspirasi. Orang lebih suka membicarakan kejelekan orang lain menurut penafsiran subjektifnya daripada mencoba untuk berbuat yang terbaik. Dengan intensitas mengunjing yang tinggi dapat menimbulkan kebodohan karena sibuk memikirkan orang lain dan lupa dengan diri sendiri. Filosofi tangan yang sedang menunjuk dapat dijadikan pelajaran bahwa jika menunjuk seseorang, maka jari satu yang ke depan dan yang empat menghadap ke belakang atau menunjuk pada dirinya sendiri dengan kata lain adalah intropeksi diri.

Adapun penggunaan tembang mijil sebagai penunjang pendidikan karakter secara aplikatif dapat disesuaikan dengan situasi dan kondisi dalam proses belajar-mengajar. Perlu dipahami bahwa yang dihadapi oleh pengajar bukanlah robot, tetapi manusia yang perlu dihargai atau diperhatikan sisi kemanusiannya. Oleh sebab itu, sudah selayaknya dalam proses belajarmengajar perlu adanya selingan atau suasana yang lain untuk menghindari kejenuhan. Memasukkan nilai-nilai kearifan lokal, terutama nilai dalam tembang dapat menjadi satu alternatif.

\section{SIMPULAN}

Pada dasarnya kajian pada penelitian ini merupakan perspektif peneliti dari sisi yang lain. Mengaitkan nilai-nilai yang terkandung dalam tembang mijil dengan keadaan saat ini dan dalam konteks pendidikan. Berdasarkan analisis larik tembang macapat, khususnya tembang mijil, maka dapat disimpulkan bahwa terdapat nilai-nilai pendidikan karakter yang dapat dijadikan tauladan bagi halayak. Nilai-nilai yang dimaksud adalah pintar, merendah, mengalah, jangan membantah, kesederhanaan, jangan megunjing. Beberapa perilaku tersebut merujuk pada nilai-nilai manusia dalam merespon situasi dan menjadi pembeda antara manusia yang satu dengan yang lainnya. Nilai-nilai karakter yang tergambar dalam tembang mijil jika disampaikan dan dilakukan oleh siapa pun, khususnya bagi remaja, lebih tepatnya anak sekolah, akan tumbuh karakter yang unggul dalam diri mereka. Suatu keniscayaan juga bahwa masyarakat dan para pelaku pendidikan mampu menggali nilai-nilai budaya atau kearifan lokal untuk memberikan stimulus dalam pembelajaran dengan nuansa yang berbeda, tentunya menggunakan media yang menarik dan menyenangkan.

\section{DAFTAR PUSTAKA}

Badan Pengembangan dan Pembinaan Bahasa. (2016). Kamus Besar Bahasa Indonesia. Jakarta: Badan Pengembangan dan Pembinaan Bahasa.

Efendi, A. (2009). Mengenal Tembang Macapat. WIDYATAMA, 20(2), 201--206.

Lickona, T. (2013). Pendidikan Karakter: Panduan Lengkap Mendidik Siswa Menjadi Pintar dan Baik. (S. Lita, Ed.) (Terjemahan). Bandung: Nusa Media.

Munir, M. I. A. (2004). Tinjauan terhadap Metode Empirisme dan Rasionalisme. Jurnal Filsafat, 14(3), 234--245. https://doi.org/https://doi.org/10.22 
146/jf.31413

Nuratni, N. K. R., Artawan, G., \& Sutresna, I. B. (2014). "Kajian Puisi Akrostik dengan Pendekatan Parafrasa untuk Meningkatkan Kemampuan Memahami Puisi Siswa Kelas VII.C di SMP Negeri 7 Singaraja." Undiksha, 2(1), 111. Retrieved from https://ejournal.undiksha.ac.id/inde x.php/JJPBS/article/view/3407

Pitaloka, D. (2017). Mijil Ludiro Pelog Pathet Barang. Jakarta: diahpitaloka publiser. Retrieved from

https://www.youtube.com/watch?v

\section{$=$ HbYD1Jf1g-E}

Rahman, F., \& Anto, P. (2015). Analisis Lirik Lagu dan Aplikasinya dalam Pembelajaran Gaya Bahasa serta Puisi di Sekolah Dasar. Jurnal Inovasi Pendidikan Dasar, 1(1), 914. Retrieved from http://jipd.uhamka.ac.id/index.php/ jipd/article/view/8

Sahlan, A., \& Mulyana. (2012). Pengaruh Islam terhadap Perkembangan Budaya Jawa: Tembang Macapat. El Harakah, 14(1), 101-114. https://doi.org/10.18860/el.v0i0. 2196 